\title{
Electricity Generation Potential Through Solar-Rice Husk Hybrid Power Plant in Nepal and Its Major Paddy Producing Districts
}

\author{
Ram Dayal Yadav ${ }^{1,2,}$, , Ajay Kumar Jha ${ }^{1}$, Nawraj Bhattarai ${ }^{1}$ \\ ${ }^{1}$ Department of Mechanical Engineering, Pulchowk Campus, Institute of Engineering, Tribhuvan University, Pulchowk, Nepal \\ ${ }^{2}$ Department of Mechanical Engineering, Purwanchal Campus, Institute of Engineering, Tribhuvan University, Dharan, Nepal
}

\section{Email address:}

rdy2027@ioe.edu.np(R. D. Yadav), akjha@ioe.edu.np(A. K. Jha), bnawraj@ioe.edu.np(N. Bhattarai)

${ }^{*}$ Corresponding author

\section{To cite this article:}

Ram Dayal Yadav, Ajay Kumar Jha, Nawraj Bhattarai. Electricity Generation Potential Through Solar-Rice Husk Hybrid Power Plant in Nepal and Its Major Paddy Producing Districts. Engineering and Applied Sciences. Vol. 3, No. 3, 2018, pp. $74-87$.

doi: $10.11648 /$ j.eas. 20180303.13

Received: August 27, 2018; Accepted: September 17, 2018; Published: October 15, 2018

\begin{abstract}
Nepal is an agricultural based country having huge potential of rice husk. Out of total electrical energy consumption in Nepal, 22\%, 34.76\% and 36.58\% were imported from India in the years 2016, 2017 and 2018 respectively. Such import can be minimized by generating electricity from solar-rice husk hybrid system. Solar plants have drawbacks of intermittency in day/night cycle and reduced irradiation in winter and cloudy days. Biomass plants have problem associated with continuous supply of seasonal fuel. Those problems can be solved using hybrid system by maximizing the energy potential of these resources, increasing process efficiency, providing greater security of supply and reducing overall cost. The objective of this paper is to estimate electricity generation potential through solar- rice husk hybrid power plant in Nepal and its major paddy producing districts through existing data and forecasting the same for future potential. From existing data, the rice husk growth rate in Nepal was found to be $2.92 \%$ and on the basis of that growth rate, future potentials were forecasted. The 20 major paddy producing districts were taken into consideration as $71.15 \%$ of total paddy production of Nepal was found to be shared by those districts. The quantity of rice husk was found assuming $20 \%$ of paddy converted into rice husk in the mills. The rice husk consumption for cattle feeding was assumed $10 \%$ of total rice husk. The electric power from rice husk was calculated assuming $1.3 \mathrm{~kg}$ consumption of rice husk for per $\mathrm{kWh}$ generation of electricity through steam route and $1.86 \mathrm{~kg}$ of rice husk consumption for per $\mathrm{kWh}$ electricity generation through gasification route. The average increase rate of land for paddy production and the average increase rate of rice husk production were found to be $0.39 \%$ and $2.92 \%$ respectively. The electrical energy potentials of Nepal for the years 2015 and 2030 with solar-rice husk hybrid power plant through steam route were found as 100.67 MW and 155.02 MW respectively and through gasification route 70.36 MW and 108.35 MW respectively. The electrical potential for Jhapa district was found the highest values of $7.10 \mathrm{MW}$ and $10.94 \mathrm{MW}$ through steam route and 4.96 MW and 7.64 MW through gasification route for the years 2015 and 2030 respectively. Thus, through solar-rice husk hybrid power plant system, large amount of electricity can be generated locally in Nepal, which in turn can reduce energy import and enhance the better life of the people.
\end{abstract}

Keywords: Rice Husk, Energy Potential, Hybrid System, Electricity Generation

\section{Introduction}

Nepal is located between India and China with 147,181 square kilometers of area. Nepal occupies 0.3 percentage of total land area of Asia and 0.03 percentage of total land area of the world. In the northern hemisphere, Nepal is situated within latitude $26^{\circ} 22^{\prime} \mathrm{N}$ to $30^{\circ} 27^{\prime} \mathrm{N}$ and of longitude $80^{\circ} 4^{\prime}$ $\mathrm{E}$ to $88^{\circ} 12^{\prime} \mathrm{E}$. The altitude ranges from a minimum of 70 meters to a maximum of 8848 meters whereas the climate varies with its topography. The average width (North to South) is 193 kilometers whereas the average length is 885 
(East to West) kilometers. The country has great variety of topography which is reflected in the diversity of weather and climate simultaneously. Specially, the country experiences tropical, meso-thermal, micro-thermal, taiga and tundra types of climate [1]. Ecologically the country is divided into three regions, running east to west. They are the Mountain, the Hill and the Terai (Plains) regions. The Mountain region has area of 51,817 sq.km. The Hill region has area of 61,345 sq.km and the Terai region has area of 34,019 sq.km [2]. In Nepal, Agriculture cultivated land is 3091 thousands of hectares, Agriculture uncultivated land is 1030 thousands of hectares, forest including shrub is 5828 thousands of hectares, grass and Pasture land is 1766 thousands of hectares, land covered by water is 383 thousands of hectares and others is 2620 thousand of hectares[2].

Nepal is facing energy crisis and research on electricity generation from rice husk-solar hybrid system has not yet been carried out in Nepal. This paper aimed to find the amount of electrical energy that can be harvested from hybrid system in Nepal, which is not yet found. Nepal having huge potential of rice husk and from that energy can be harvested and that can be utilized in generating electricity through solar-rice husk hybrid system locally which in turn not only minimizes the energy crisis but also enhances the better life of people. The hybrid power plant systems are those which generate power from more than one energy resources.

The demand of energy of Nepal is increasing rapidly. The annual peak power demand of the Integrated Nepal Power System (INPS) in year 2014 was estimated to be 1,201 MW, with $410 \mathrm{MW}$ power estimated to have been shed. Out of the 791 MW of power actually supplied, 436.4 MW was contributed by Nepal Electrical Authority( NEA) hydro, 22 MW by NEA thermal, 216.4 MW by Independent Power Producer (IPP) hydro and the rest 116.2 MW was import. Compared to the preceding fiscal year's figure of 1,094.6 MW, the annual peak power demand of the INPS registered a growth rate of $9.7 \%$. Energy demand of INPS in year 2014 was estimated to be $1641.7 \mathrm{MW}$, out of which only 1286.5 MW (78.4\%) could be supplied. The rest 355.1 MW (21.6\%) was resorted to load shedding. Of the total supplied energy volume, 988.7 MW (76.8\%) was contributed by domestic generation and 297.8 MW (23.2\%) by import from India. Domestic supply included 349.7 MW (35.4\%) from IPPs and the rest $638.9 \mathrm{MW}(64.6 \%)$ was from NEA owned power stations with a share of 636.3 MW from hydro and 2.7 MW from thermal [3]. The electricity import from India is found to be increasing. Out of total electrical energy consumption in Nepal, $22 \%, 34.76 \%$ and $36.58 \%$ were imported from India in the years 2016, 2017 and 2018 respectively [3].

The energy consumption of 2015 of Nepal showed that fuel wood consumption is $70.47 \%$, agriculture residue as $3.48 \%$, animal dung $3.68 \%$, coal as $3.97 \%$, petroleum $12.53 \%$, electricity $3.39 \%$ and renewable energy $2.49 \%$ [4]. There will have been $30 \%$ demand of electricity by 2020 compared to that with 2015 . The actual installed capacity requirement was $1721 \mathrm{MW}$ in the year 2015 , but hardly 800 MW installed capacity led load shedding. As per last trend of
GDP growth rate of $4.5 \%$, there would be a need of 3384 MW of installed capacity by the year 2020 , whereas in case of policy intervention scenario the requirement will be 6621 MW. By 2030, instalment capacity requirement is 15000 MW, whereas by 2040 , demand will increase to $82000 \mathrm{GWh}$ for which the corresponding installed capacity will more than $35000 \mathrm{MW}$ [4].

The caloric value of rice husks lies between 13 to 19 $\mathrm{MJ} / \mathrm{kg}$; the average is closer to the higher heating value of 18 $\mathrm{MJ} / \mathrm{kg}$ [5]. One ton of paddy can produce $220 \mathrm{~kg}$ of rice husk [6].

The Ministry of New and Renewable Energy in India has been promoting biomass gasification projects under various schemes and it is reported that there are 60 mini rice husk powered electricity plants operating in various parts of the country. There is a single $250 \mathrm{~kW}$ rice-husk based power plant operating in Bangladesh (namely Dreams Power Limited in Gazipur). The first plant of DESI Power was set up in 1996 in a village in Madhya Pradesh (India) and relied on biomass gasification systems. It has set up 16 power plants in total by 2012, with installed capacities ranging between $11 \mathrm{~kW}$ and $120 \mathrm{~kW}$ [7]. The different energy producing companies have shown interest for generating electrical power from hybrid system in different parts of India. For example, Bermaco Energy System Limited has shown interest for generation of $12 \mathrm{MW}$ at Gawanaha, champaran districts, Bihar; User Eco Power Ltd. for generation of $3 \mathrm{MW}$ in Mathura, U.P.; Dee Development Engineer's Ltd for generation of 10 MW in Muktsar, Punjab of India [8].

The major paddy production is found in village areas of Nepal. In urban areas mixed waste are collected and are used for land fill. The rice husk in village areas are mainly used for cattle feeding, used as fuel in cooking, in few industries for burning in furnace and remaining are either burnt in winter or directly disposed to the land. Local bodies are facing difficulties in developing management plans due to the lack of Sustainable Waste Management (SWM) baseline information and data related to the functional elements of SWM. It is essential to know the quantity and composition of Municipal Solid Waste (MSW) when designing and implementing proper waste management plans that include resource recovery through appropriate methods [9]. Thus, the use Rice husk for power generation with solar-rice husk hybrid power plant would not only solve the waste management problem but also local people would get benefit by getting electricity, which in turn enhances the better life of people.

\section{Methodology}

The methodology includes the collection of data for paddy of Nepal and its all 75 districts [1] and mapping the same for the base year 2015 using GIS Arc Map. Quantity of rice husk was obtained assuming $20 \%$ [10] of paddy converted into the rice husk in the rice mills. 


$$
\mathrm{TRHB}=\mathrm{P}_{\mathrm{j}} \times \mathrm{F}
$$

Where, $\quad$ TRHB $=$ Total rice husk biomass availability at jth location

$$
P_{j}=\text { paddy availability at jth location }
$$

$$
\mathrm{F}=\text { conversion factor of rice husk from paddy }=20 \%
$$

The consumption of rice husk for cattle feeding is assumed $5 \%$ to $10 \%$ of the total rice husk production [11]. In this paper it was assumed as $10 \%$.

$$
\mathrm{PRHB}=\mathrm{P}_{\mathrm{j}} \times \mathrm{F} \times(1-\mathrm{K})
$$

Where,

$$
\begin{gathered}
\text { PRBH }=\text { Practical availibility of rice husk excluding cattle feeding } \\
\mathrm{K}=\text { percentage consumption of rice husk for cattle feeding }=10 \%
\end{gathered}
$$

The average annual rice husk growth rate for Nepal was calculated by averaging the growth rate of rice husk from the year 1978 to 2015 and on the basis that growth rate the potential of rice husk was forecasted up to the year 2030 assuming the year 2015 as the base year.

$$
\mathrm{P}_{\mathrm{i}}=\mathrm{P}_{(\mathrm{i}-1)} \times(1+\mathrm{R})
$$

Where,

$$
\begin{gathered}
\mathrm{P}_{\mathrm{i}}=\text { Production of paddy in ith year } \\
\mathrm{P}_{(\mathrm{i}-1)}=\text { Production of paddy in }(\mathrm{i}-1) \text { th year } \\
\mathrm{R}=\text { Average paddy grouth rate }=2.29 \%
\end{gathered}
$$

The electric power from the rice husk was calculated assuming $1.3 \mathrm{~kg}$ consumption of rice husk for per $\mathrm{kWh}$ generation of electricity through steam route and $1.86 \mathrm{~kg}$ of rice husk consumption for per $\mathrm{kWh}$ electricity generation through gasification route [12].

$$
\begin{aligned}
\text { RHBES } & =\frac{\sum_{\mathrm{i}=1}^{\mathrm{n}} \mathrm{P}_{(\mathrm{i}-1)} \times(1+\mathrm{R}) \times \mathrm{F} \times(1-\mathrm{K})}{1.3} \\
\text { RHBEG } & =\frac{\sum_{\mathrm{i}=1}^{\mathrm{n}} \mathrm{P}_{(\mathrm{i}-1)} \times(1+\mathrm{R}) \times \mathrm{F} \times(1-\mathrm{K})}{1.86}
\end{aligned}
$$

Where,

$$
\begin{gathered}
\text { RHBES = Electrical energy from rice husk biomass through steam route in } \mathrm{kWh} \\
\text { RHBEG = Electrical energy from rice husk biomass through gasification route in } \mathrm{kWh}
\end{gathered}
$$

For districts, the same average growth rate was assumed for their future potential. For solar-rice husk hybrid power plant, the plant was assumed to run full load in night where only rice husk is used and in day time $50 \%$ of heat is assumed to be supplied through solar thermal and remaining from rice husk for generation of steam for steam turbine [13]. Thus the total energy through hybrid system would be

$$
\begin{aligned}
& \text { TRHBES }=\frac{\sum_{\mathrm{i}=1}^{\mathrm{n}} \mathrm{P}_{(\mathrm{i}-1)} \times(1+\mathrm{R}) \times \mathrm{F} \times(1-\mathrm{K})}{1.3} \times 1.25 \\
& \text { TRHBEG }=\frac{\sum_{\mathrm{i}=1}^{\mathrm{n}} \mathrm{P}_{(\mathrm{i}-1)} \times(1+\mathrm{R}) \times \mathrm{F} \times(1-\mathrm{K})}{1.86} \times 1.25
\end{aligned}
$$

Where,

$$
\begin{aligned}
& \text { TRHBES }=\text { Total electrical energy from solar }- \text { rice husk hybrid system through steam route in } \mathrm{kWh} . \\
& \text { RHBEG }=\text { Electrical energy from solar }- \text { rice husk hybrid system through gasification route in } \mathrm{kWh} .
\end{aligned}
$$

Finally, the electrical potential from hybrid system was mapped using GIS Arc Map.

\section{Result and Discussion}

\subsection{Amount of Land Used for Paddy and Paddy Production in Nepal}

The land used for paddy production is shown in figure 1 from the year 1977 to the year 2015. Land used for Paddy is seen to be maximum in the year 2009 (1572.13 thousands of hectares) and the minimum in the year 1980 (1254.24 thousands of hectares). The trend line in the figure showed that the land used for paddy was increasing. This may be the cause of deforestation in Nepal. The average increased rate of land for paddy was found to be $0.39 \%$. The land used for paddy in the base year 2015 was found to be 1420.57 thousands of hectares. The paddy production of Nepal was found to be 4788.59 thousand of metric ton in the base year 2015. The paddy production of its all 75 districts for the base year 2015 are mapped using Arc GIS map and is shown in figure 2. It was found Jhapa district having the highest production capacity. 


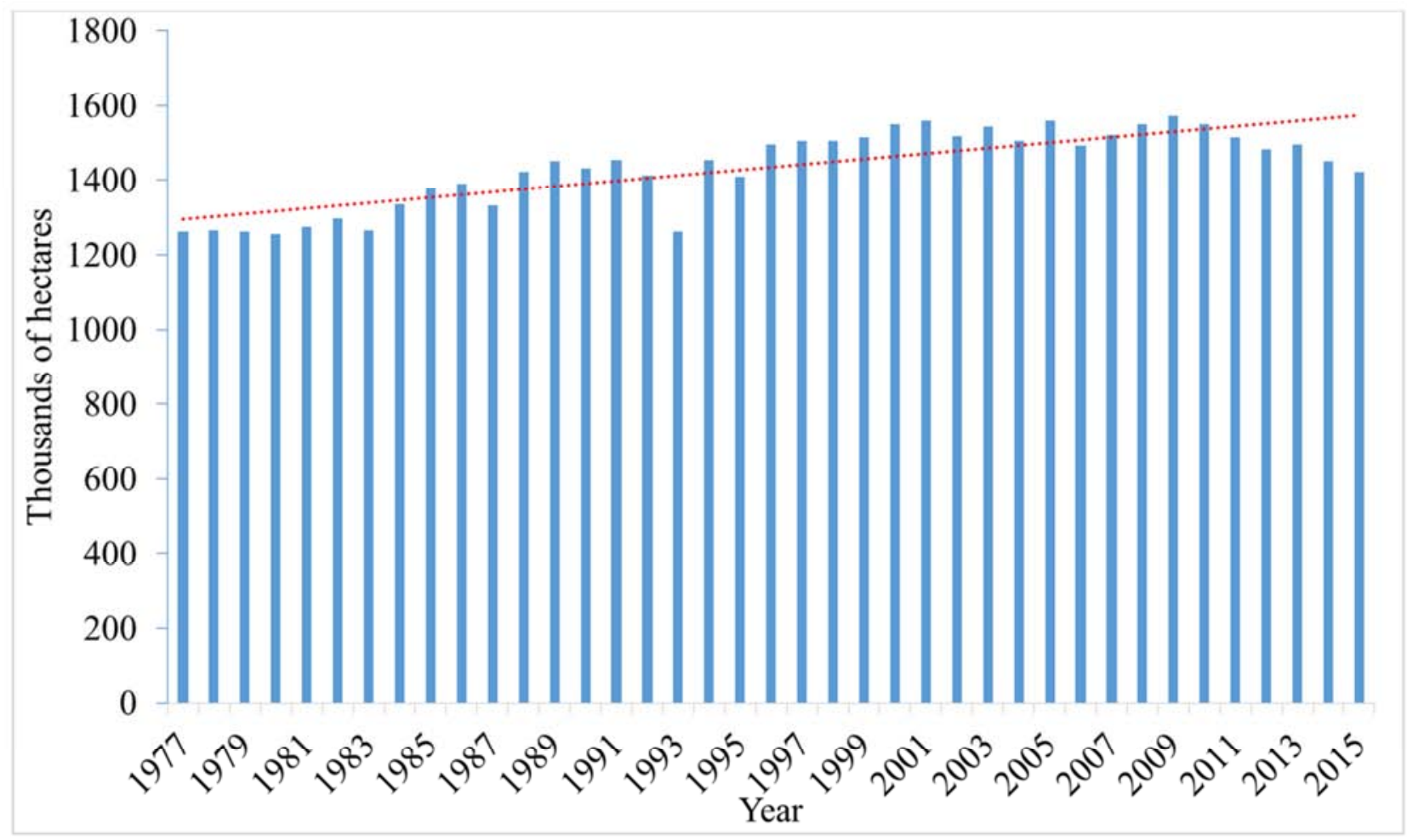

Figure 1. Amount of Land Used for paddy in Nepal.

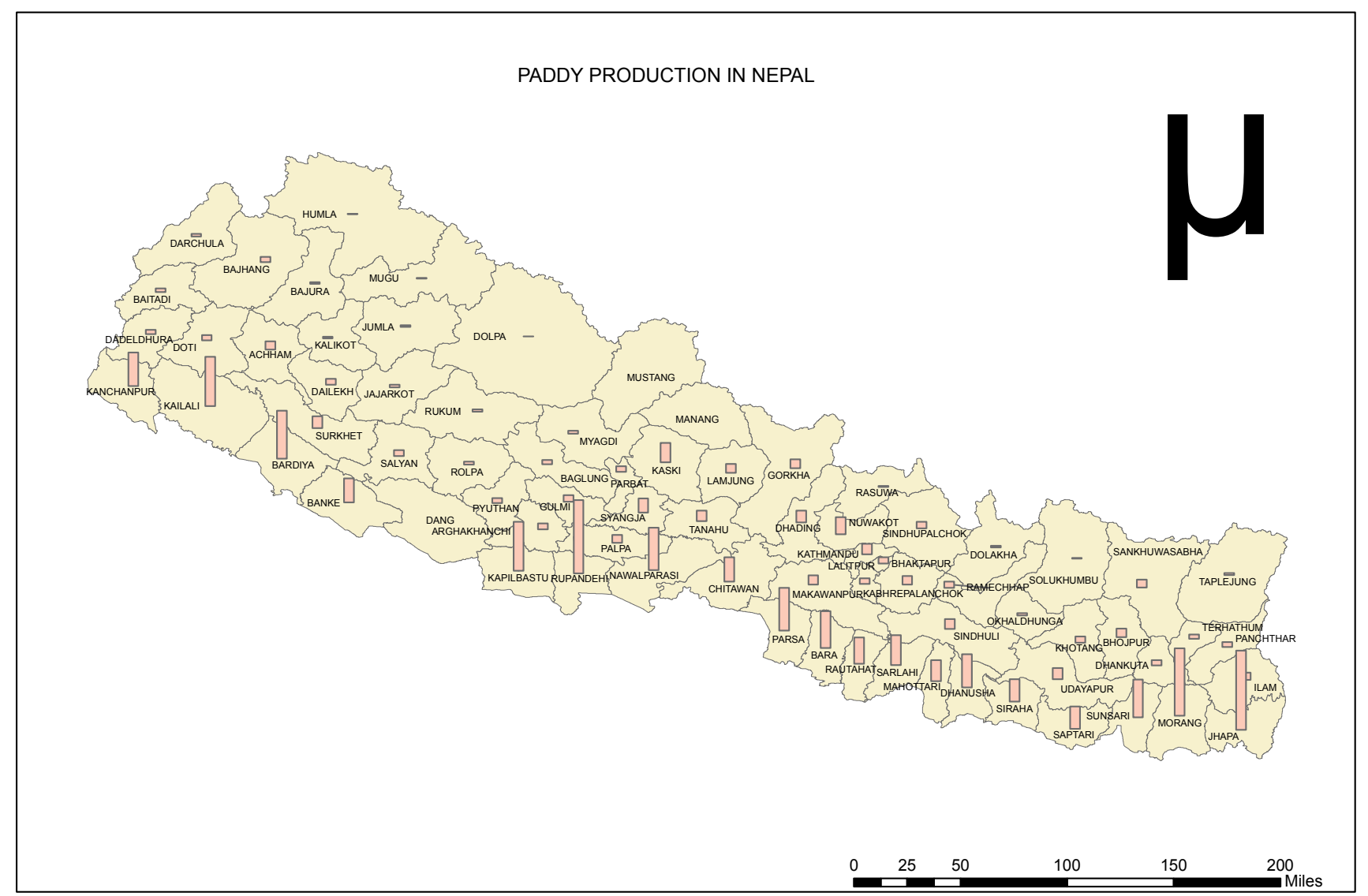

Figure 2. Paddy production of 75 districts of Nepal in the year 2015.

The land used for paddy production by 20 major rice producing districts from the years 1977 to 2015 are shown in figure 3 and for the base year 2015 in the figure 4. It was seen that Jhapa district was the highest and Mahottari district 
the lowest land user district for paddy production among the 20 major rice producing districts considered for the year 2015. Land used for Paddy production in Jhapa district was found to be 83.2 thousands of hectares and that for Mahottari district 29.4 thousands of hectares for the years 2015 .

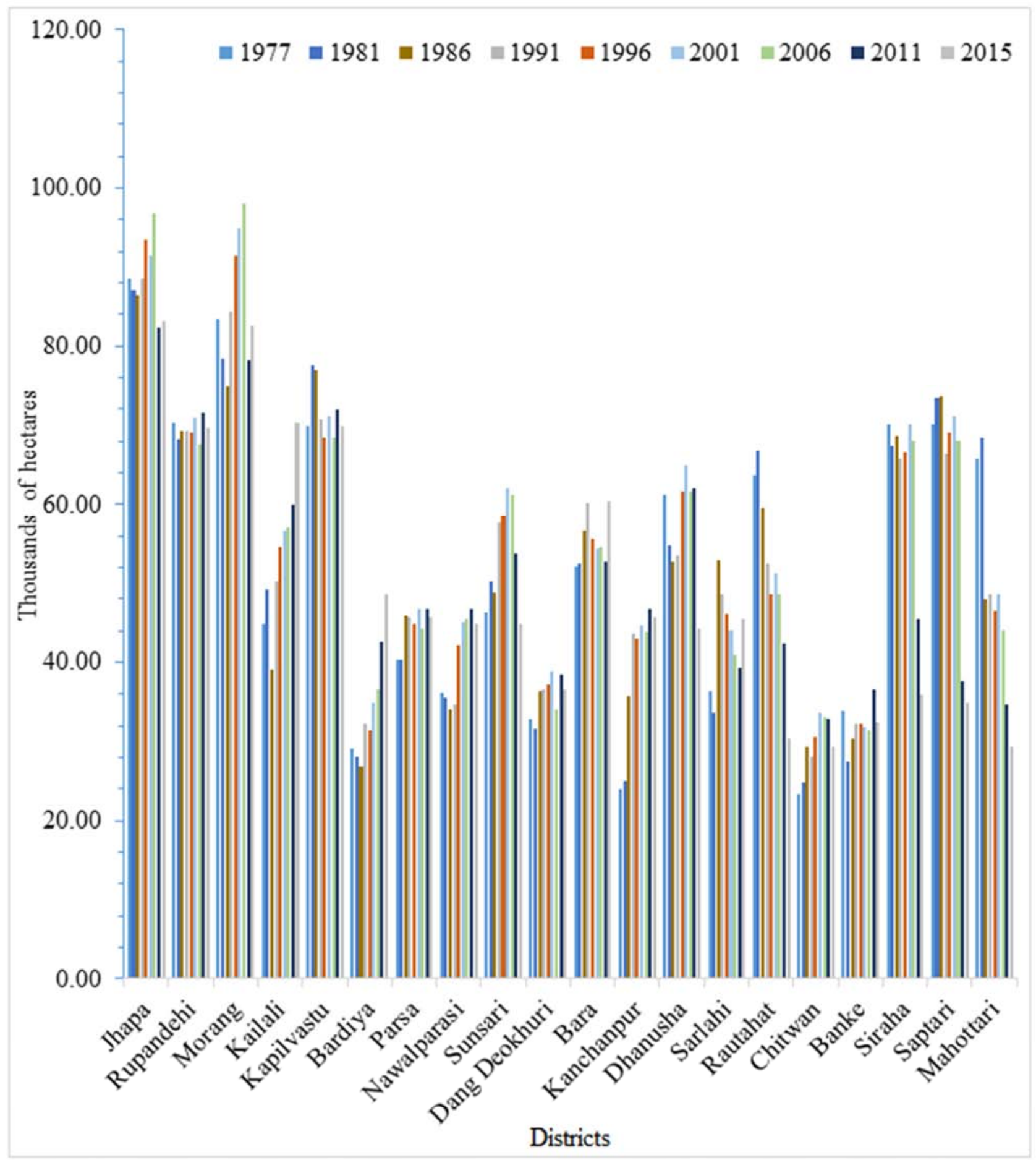

Figure 3. Land used by 20 major rice producing districts. 


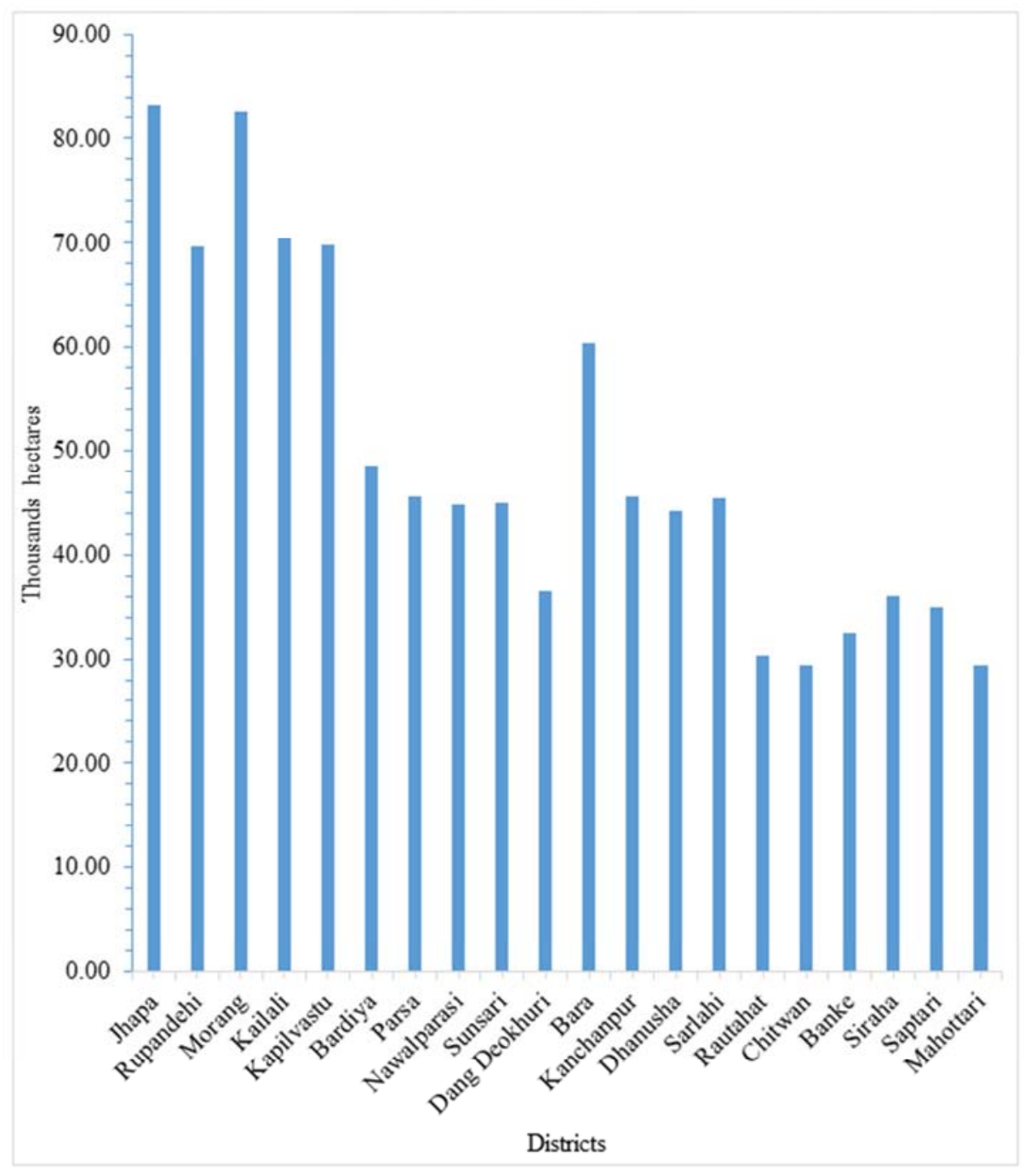

Figure 4. Land used by 20 districts in base year 2015.

\subsection{Paddy Production Per Hectare in Nepal}

Paddy production per hectare in Nepal from the year 1977 to the year 2015 were calculated and is shown in figure 5 . The trend line in the figure showed that paddy production per hectare in Nepal was increasing. The average paddy production per hectare was found to be 2.42 metric ton per hectare. The growth rate of paddy production per hectare was calculated and it was found to be $2.29 \%$.

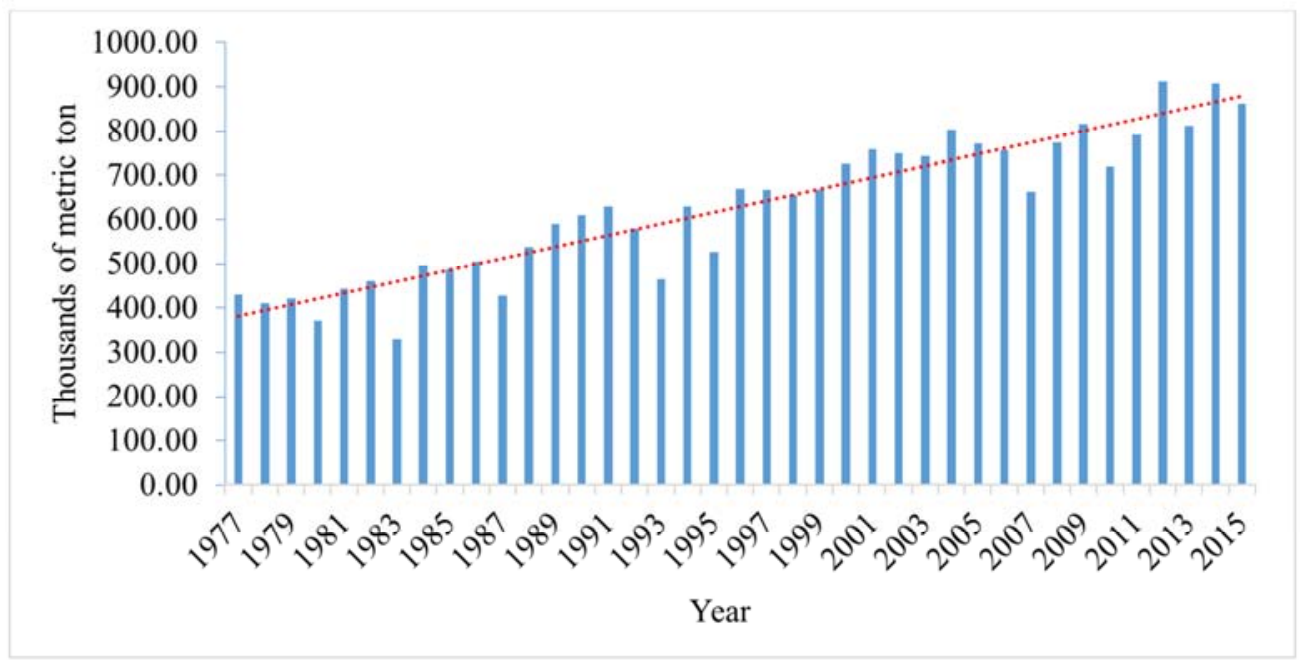

Figure 5. Paddy production per hectare in Nepal. 


\subsection{Potential of Rice Husk in Nepal}

The rice husk potential for Nepal from the year 1977 to 2015 were calculated assuming $20 \%$ of husk produced from the paddy in rice mill and is shown in figure 6 . The rice husk potential for the base year 2015 was found to be 861.95 thousands of metric ton.

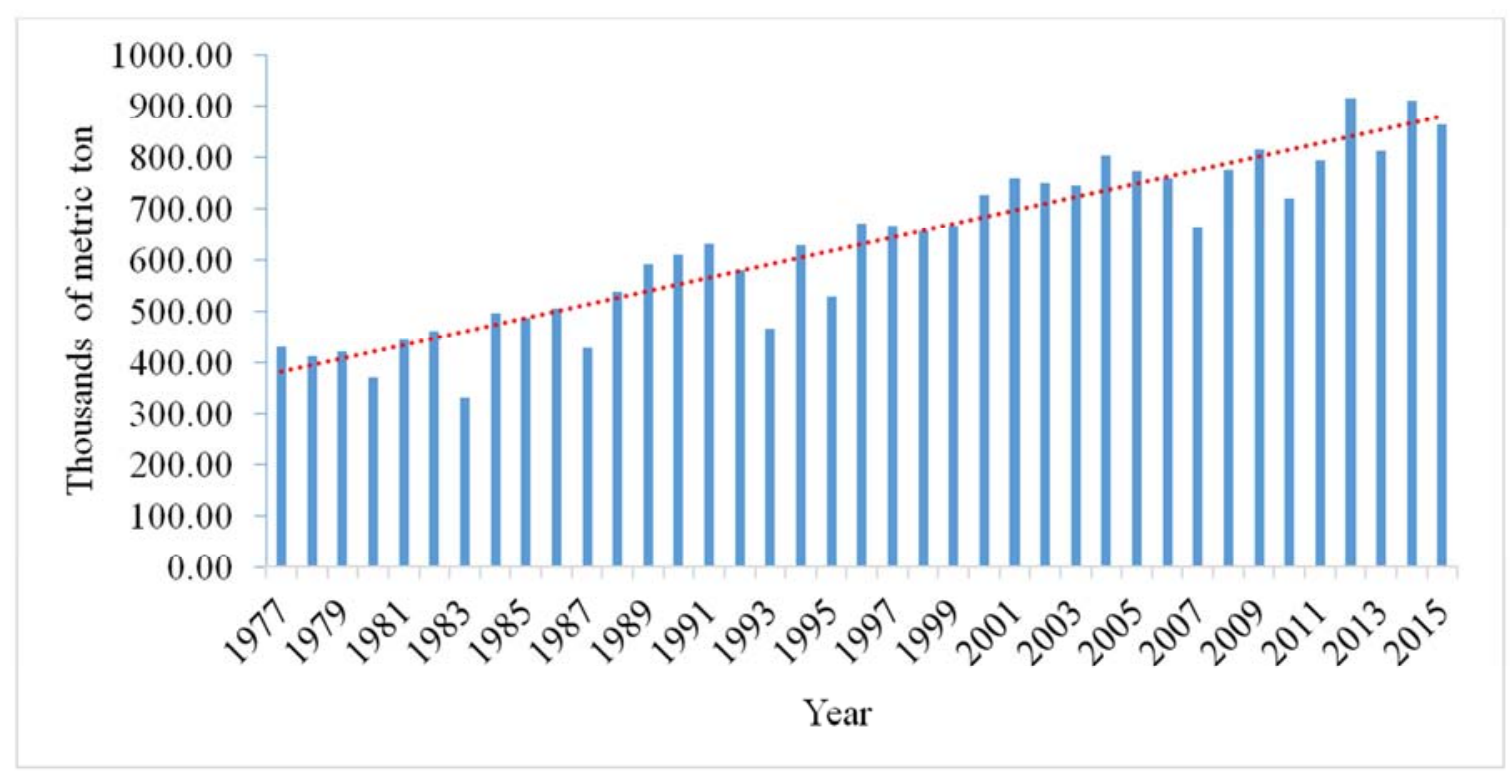

Figure 6. Rice husk potential of Nepal.

The growth rate of rice husk per year were calculated from the year 1978 to the year 2015 and then average growth rate of rice husk per year was calculated and was found to be $2.92 \%$. The potential of rice husk was computed up to the year 2030 assuming growth rate as $2.92 \%$ and is shown in the figure 7 . Accordingly, the potential of rice husk in the year 2030 would be 1327.32 thousands of metric ton.

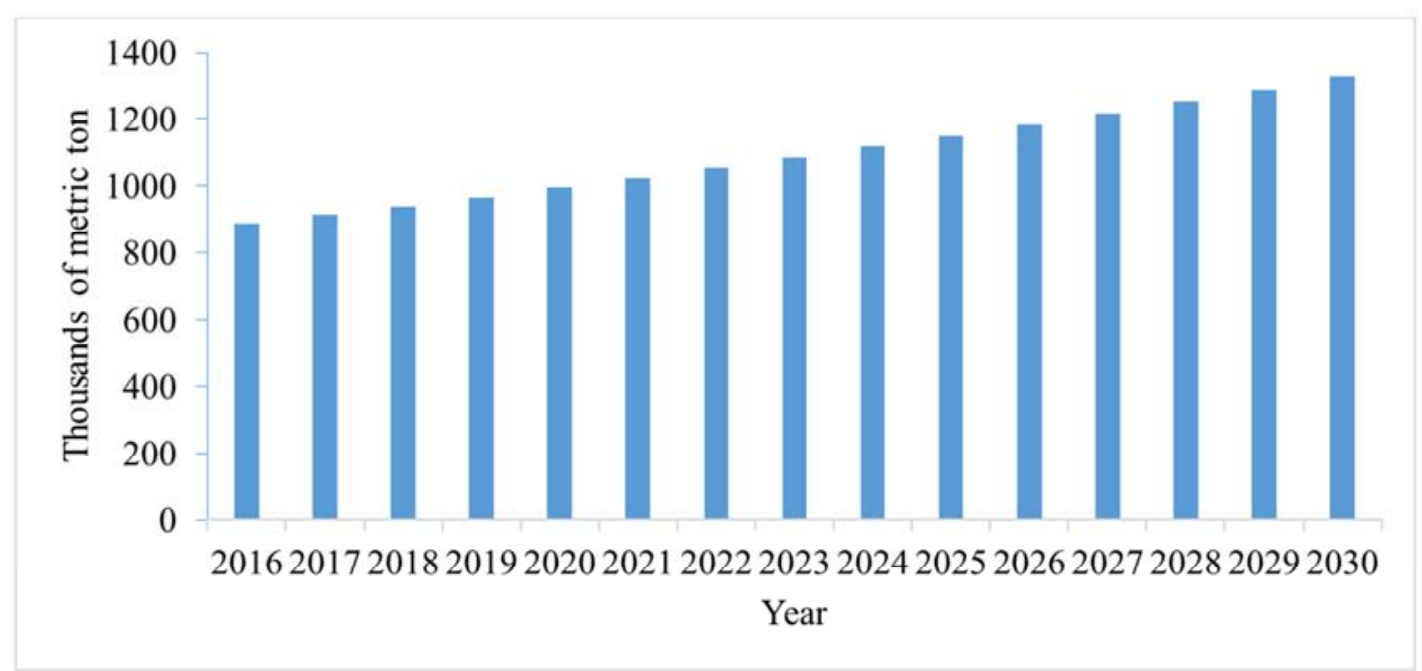

Figure 7. Rice husk potential up to 2030 of Nepal.

The rice husk potential of all 75 districts of Nepal were calculated. The potential of Manag and Mustang districts were found to be negligible. Out of the remaining 73 paddy producing districts, 20 major rice producing districts were taken into consideration as their share of production was found to be $71.15 \%$ of the total production of Nepal. These districts are Jhapa, Rupandehi, Morang, Kailali, Kapilvastu, Bardiya, Parsa, Nawalparasi, Sunsari, Dang Deokhuri, Bara,
Kanchanpur, Dhanusha, Sarlahi, Rautahat, Chitwan, Banke, Siraha, Saptari and Mahottari in descending order based on their potential of rice husk for the base year 2015. Rice husk potential of 20 districts are shown in figure 8 from the year 1977 to the year 2015. For the base year 2015, the potential of Jhapa district was found the highest with 60.80 thousands of metric ton and the potential of Mahottari district the lowest with 16.29 thousands of metric ton. 


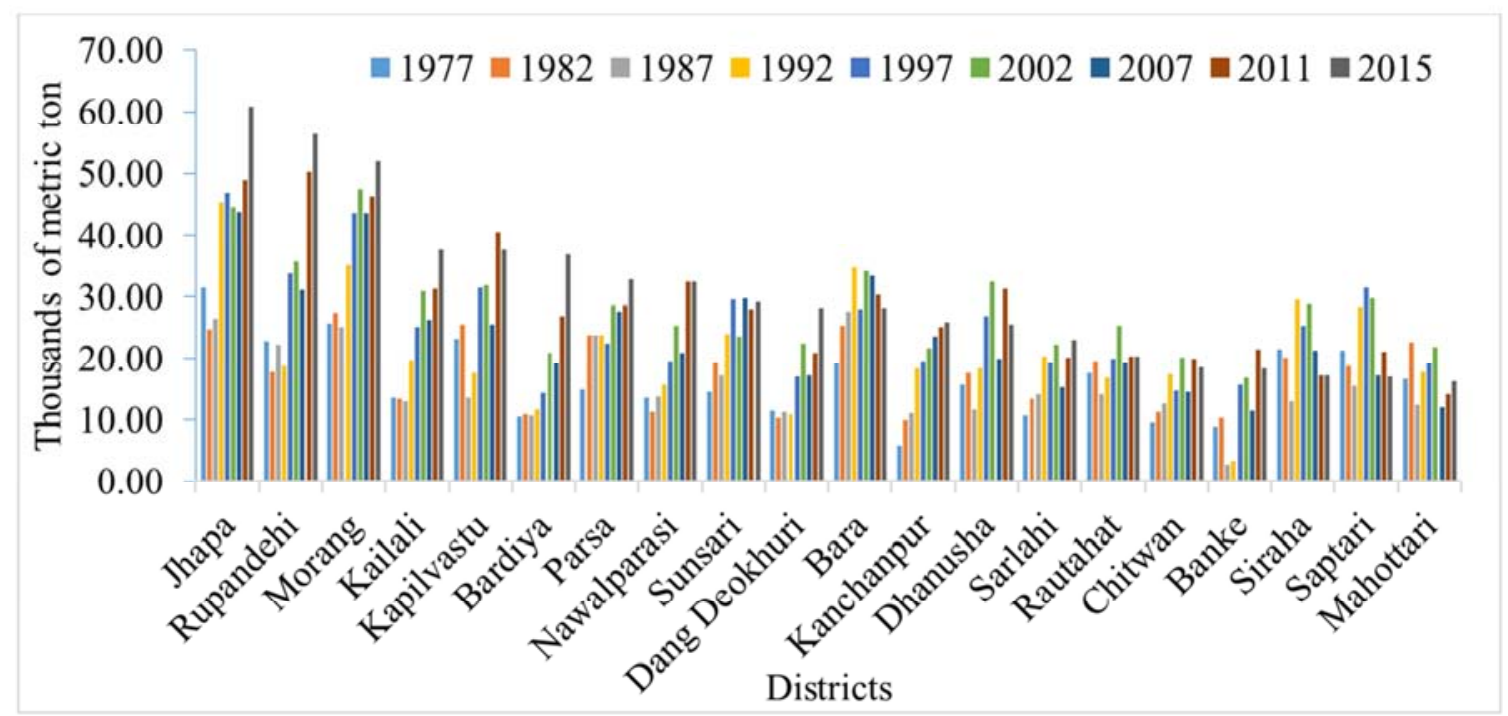

Figure 8. Potential of rice husk for 20 major paddy producing districts.

The future potential of rice husk for the 20 districts were computed up to the year 2030 assuming the growth rate of $2.92 \%$ and are shown in figure 9. It was found that the potential of rice husk for Jhapa district would be 93.63 thousand of metric ton and that for Mahottari district would be 25.09 thousands of metric ton in the year 2030 .

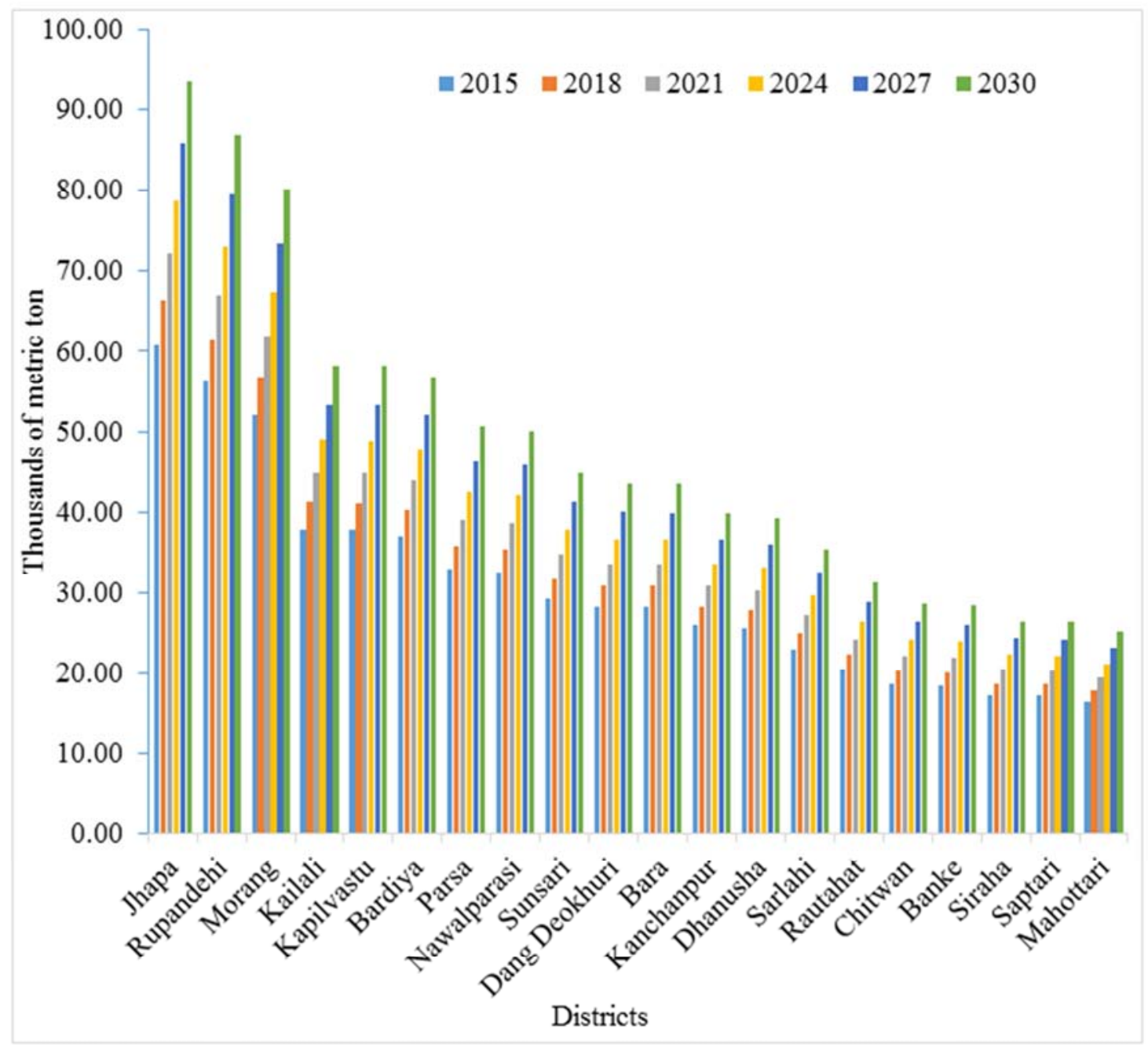

Figure 9. Potential of rice husk up to the year 2030 for 20 districts. 


\subsection{GDP of Nepal}

The annual GDP for Nepal were collected from the year 1961 to the year 2017 [14] and then annual GDP growth rate were calculated, which is shown in the figure 10. The average annual growth rate of GDP was found to be $-1.49 \%$. That showed the GDP growth rate was decreasing.

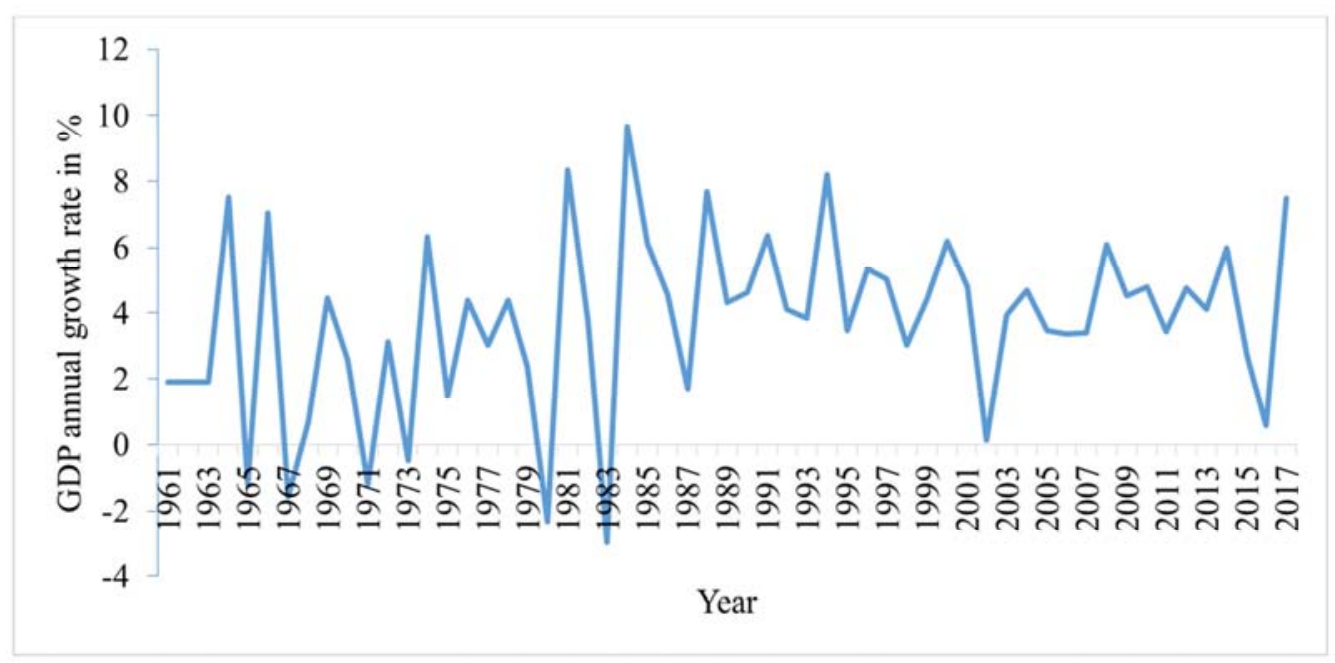

Figure 10. GDP growth rate of Nepal.

The annual GDP for agriculture were taken from the year 1966 to the year 2016 [15] and their annual growth rate were found, which is shown in the figure 11. The average agriculture annual GDP growth rate was calculated and was found to be $2.71 \%$.

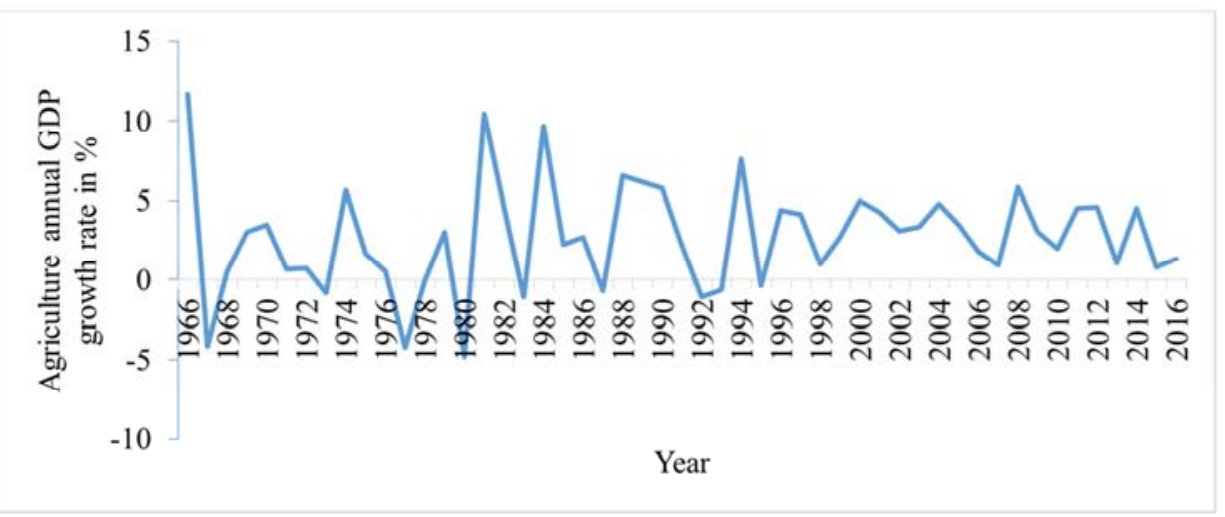

Figure 11. Annual agriculture GDP growth rate of Nepal.

The GDP shared by the paddy for Nepal was calculated from the year 2002 to the year 2017 and is shown in figure 12 [16]. The average increment of GDP shared by paddy from the year 2003 to year 2017 was calculated and was found to be $-0.03 \%$.

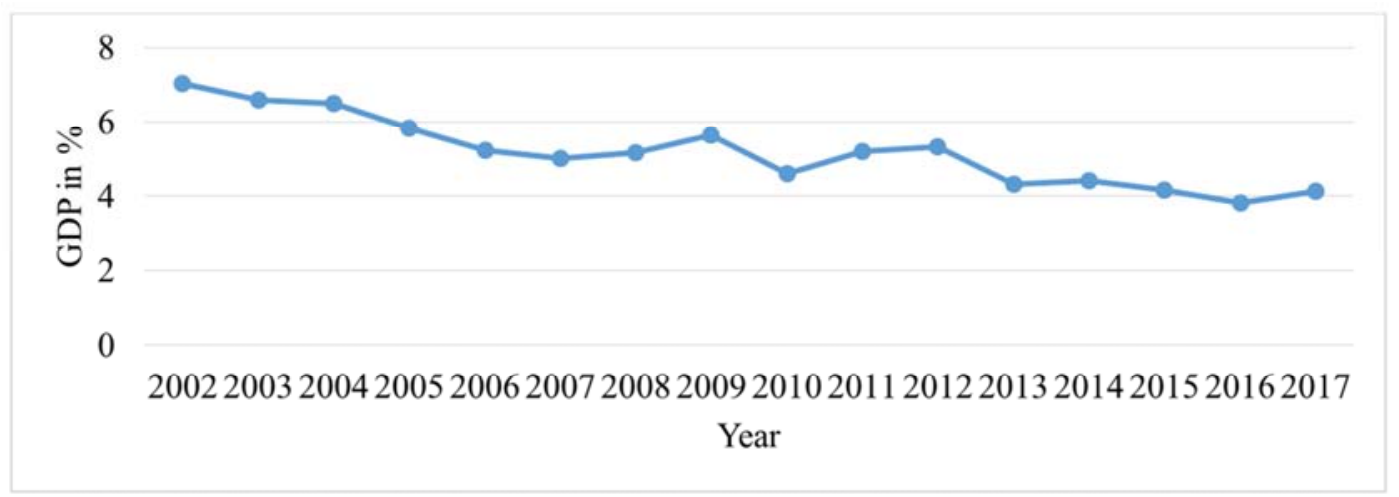

Figure 12. Share of GDP by paddy in total GDP of Nepal. 


\subsection{Cattle Production in Nepal}

The cattle production in Nepal from the year 2004 to 2015 is shown in the figure 13 [1]. Its each year growth rate was calculated and from that the average annual growth rate was found to $0.35 \%$.

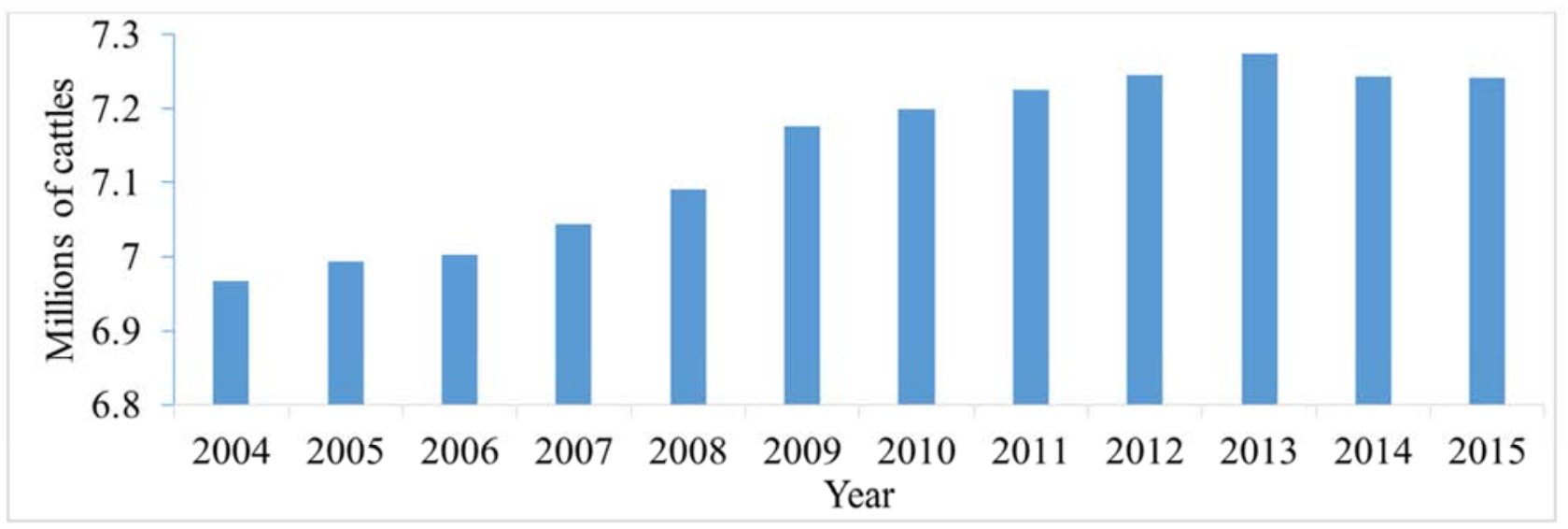

Figure 13. Cattle production in Nepal.

\subsection{Fertilizer Consumption in Nepal}

The fertilizer consumption in Nepal was collected from the year 2003 to 2015[1] and is shown in the figure 14. It was seen that the use of fertilizer was decreasing up to the year
2009 and thereafter its use was increased. The average annual incensement of the fertilizer consumption was found to $48.39 \%$. This is the one of the factor that leads increase in paddy production in Nepal.

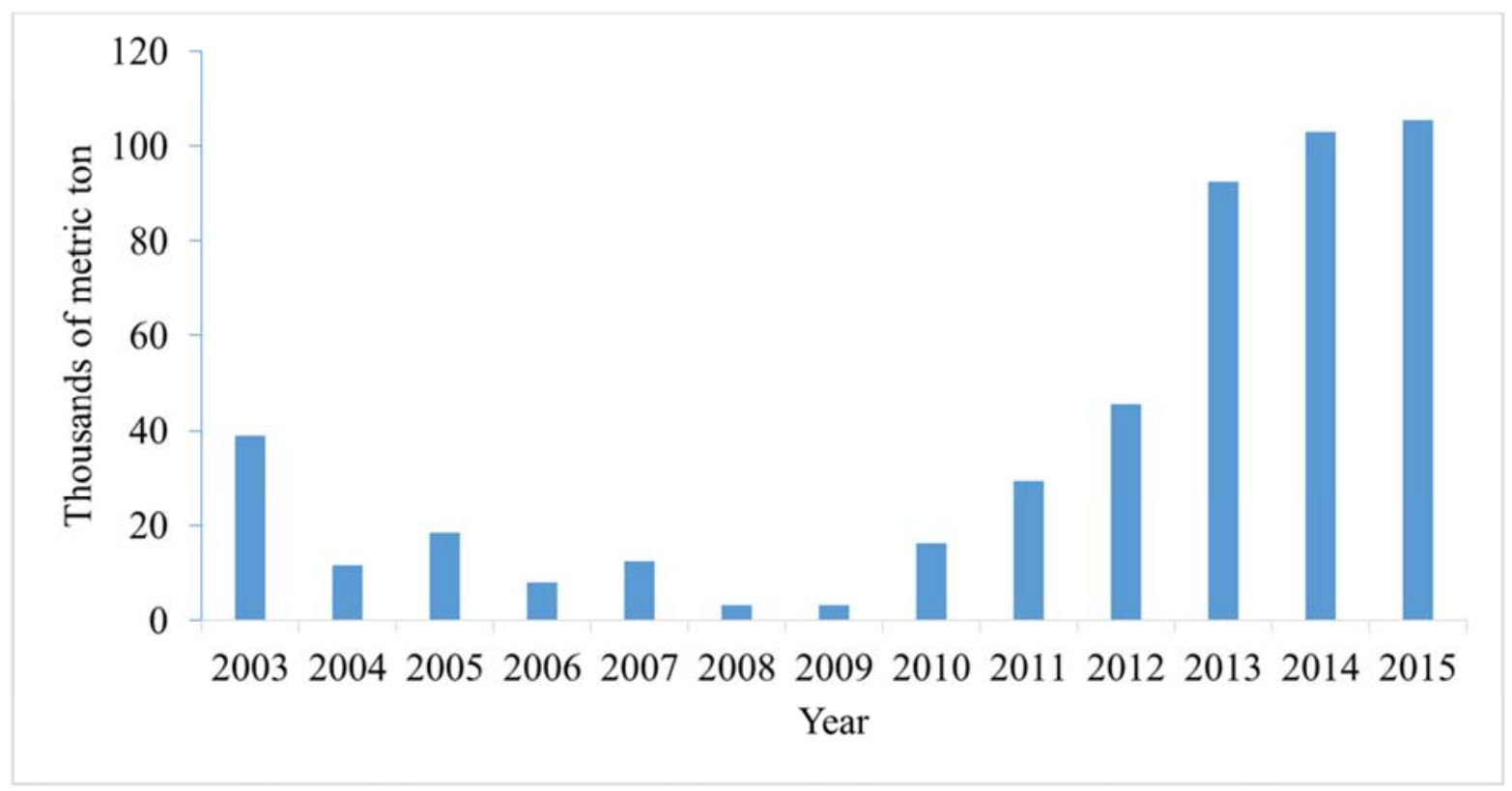

Figure 14. Fertilizer consumption in Nepal.

\subsection{Population Growth Rate of Nepal}

The annual population growth rate of Nepal was collected from the year 1960 to the year 2016, figure 15 [17]. The average annual growth rate of population was calculated by averaging the annual growth rate of population from year 1960 to the year 2016 and was found to be $1.88 \%$. 


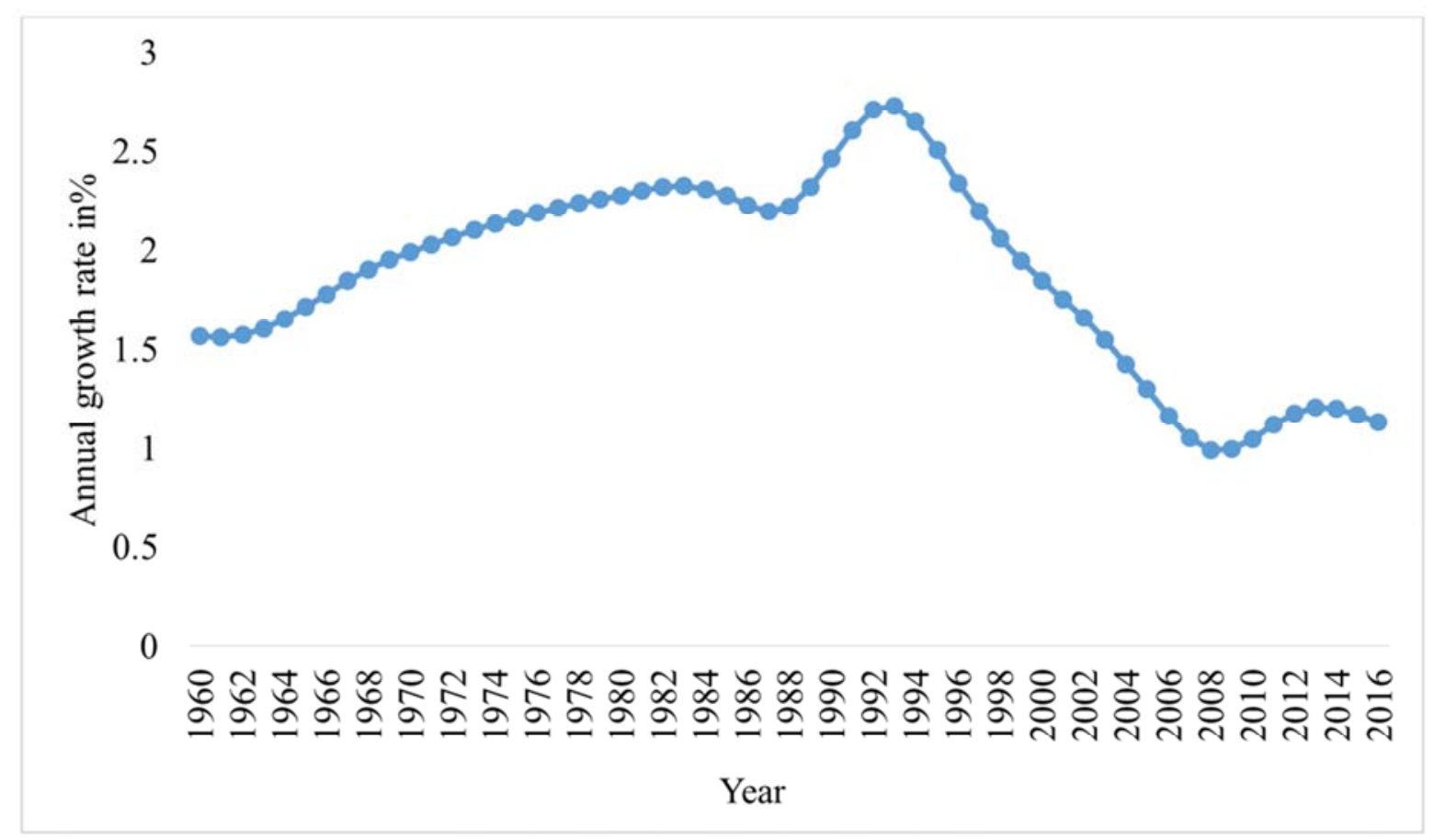

Figure 15. Population growth rate of Nepal.

\subsection{Electrical Potential from Solar-Rice Husk Hybrid Power Plant in Nepal}

The electrical potential energy of Nepal through solar-rice husk hybrid power plant was calculated for the base year 2015 and it was predicted up to the year 2030, as shown in figure 16. It was seen that electricity potential for the years
2015 and 2030 as $100.67 \mathrm{MW}$ and $155.02 \mathrm{MW}$ respectively if electricity would be generated through solar-rice husk steam power plant. The same values were found to be 70.36 MW and 108.35 MW for the years 2015 and 2030 respectively, if electricity would be generated through gasification route in hybrid power plant.

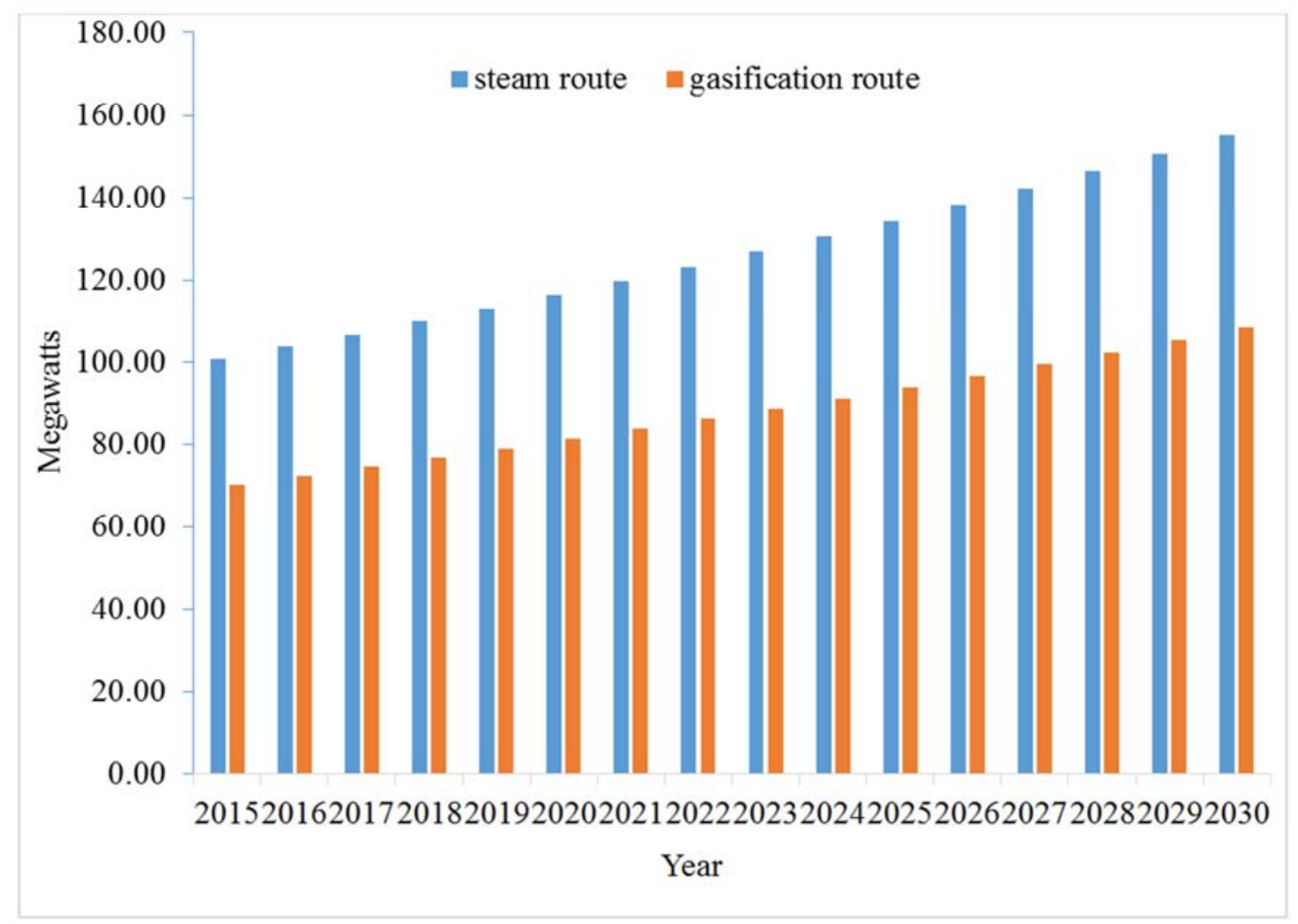

Figure 16. Energy potential from hybrid solar-rice husk fueled power plants in Nepal. 
The electrical potential through hybrid power plant of 20 major paddy producing districts were calculated for the base year 2015 and their values were predicted up to the year 2030. The figure 17 shows the electrical energy potential of 20 districts through solar-rice husk hybrid power plant from the year 2015 to the year 2030, if steam route is followed. It was seen that Jhapa district having the highest electrical potential of 7.10 MW and 10.94 MW for the years 2015 and 2030 respectively and the Mahottari district having the lowest electrical potential of 1.90 MW and 2.93 MW for the years 2015 and 2030 respectively among the 20 major paddy producing districts considered.

The figure 18 shows the electrical potential of 20 districts from the year 2015 to the year 2030 if gasification route is followed through the solar-rice husk hybrid power plant. It was seen that Jhapa district having the highest electrical potential of 4.96 MW and 7.64 MW for the years 2015 and 2030 respectively. The same values was found to be lowest for Mahottari district as $1.33 \mathrm{MW}$ and $2.05 \mathrm{MW}$ for the years 2015 and 2030 respectively.

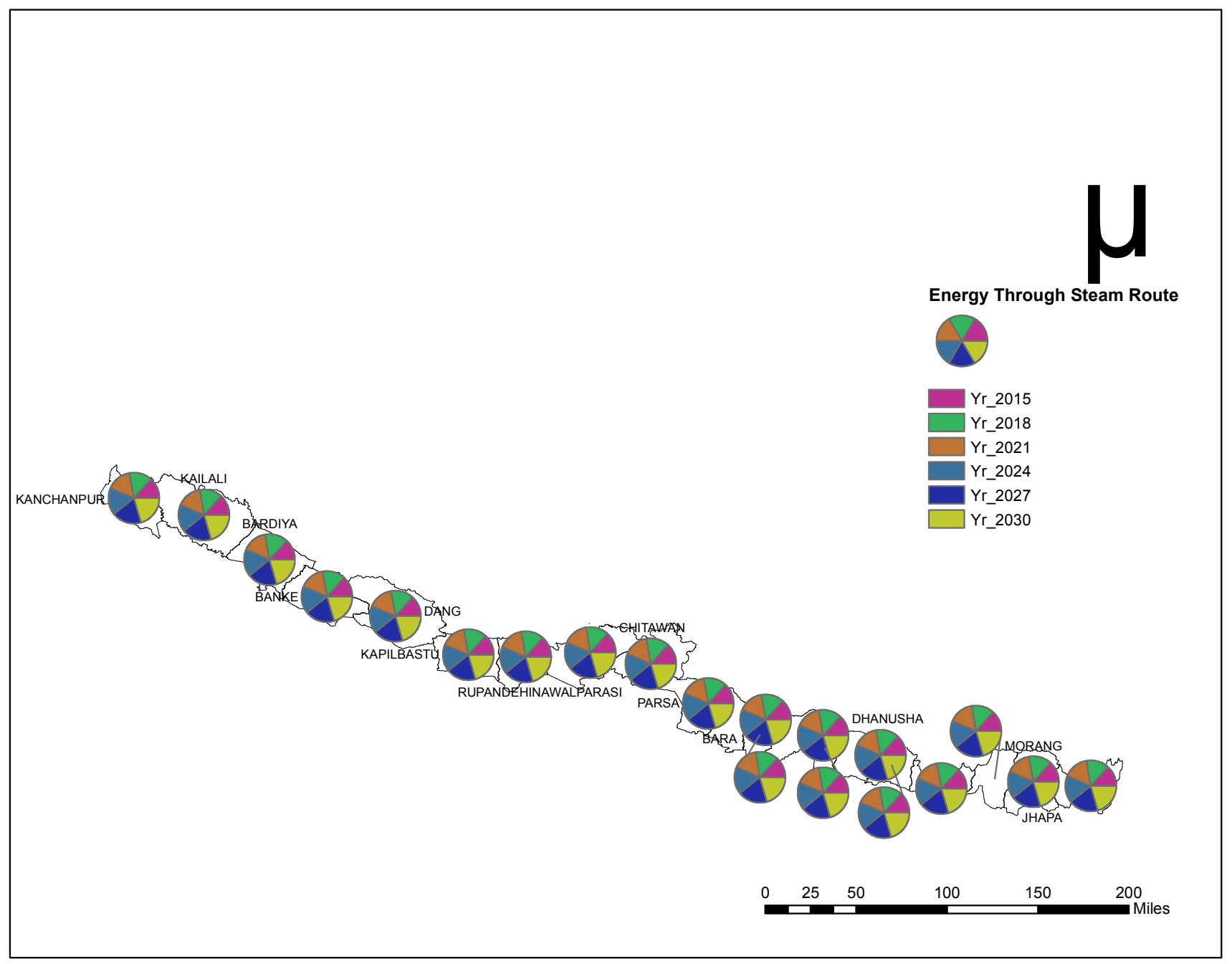

Figure 17. Electrical potential for 20 districts through hybrid power plant (steam route) of Nepal in MW. 


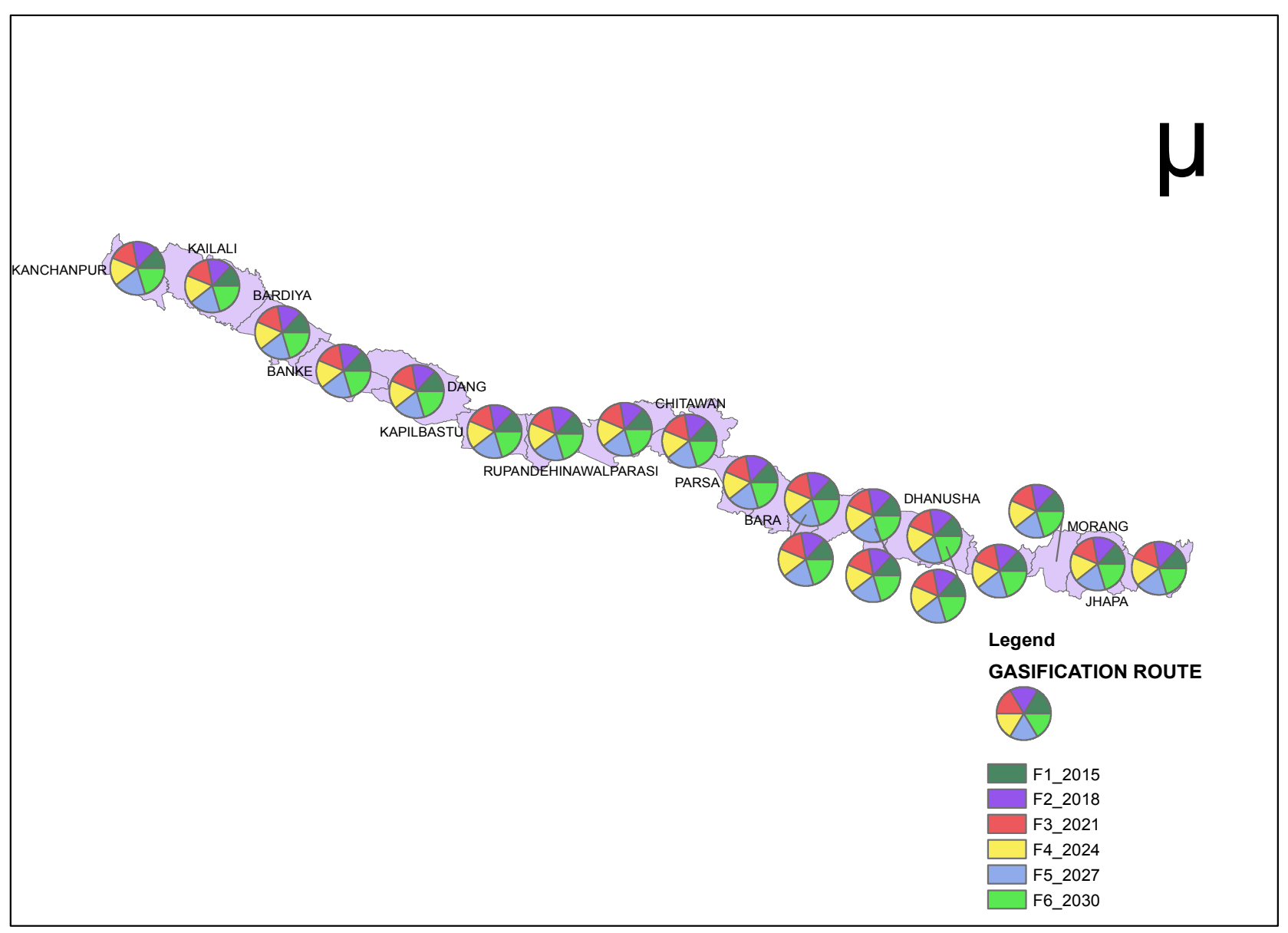

Figure 18. Electrical potential for 20 districts through hybrid power plant (gasification route) of Nepal in MW.

\section{Conclusion}

This research showed that overall land used for paddy production in Nepal was increasing. The average increase rate of land used for paddy being $0.39 \%$. Similarly, the average production of rice husk in Nepal was found to be increasing. The average increase rate of rice husk production being $2.92 \%$. The electrical energy potential with solar- rice husk hybrid plant through steam route would have generation potential of $155.02 \mathrm{MW}$ in the year 2030 compared to 100.67 MW in base year 2015. The same potential would be 108.35 MW in 2030, if electricity is generated through gasification route compared to $70.36 \mathrm{MW}$ in base year 2015 .

Out of 20 districts considered, electrical potential through hybrid system for Jhapa district was found to be the highest and for Mahottary district the lowest. The electrical energy potential through the solar-rice husk hybrid system for Jhapa district was found to be $7.10 \mathrm{MW}$ and $10.94 \mathrm{MW}$ for the years 2015 and 2030 respectively through steam route and $1.90 \mathrm{MW}$ and $2.93 \mathrm{MW}$ for the years 2015 and 2030 respectively through gasification route.

Thus, through solar-rice husk hybrid power plant system, large amount of electricity can be generated locally in rice growing sectors of Nepal, which in turn can reduce energy crisis and enhance the better life of the people.

\section{Recommendation for Further Research}

Appropriate design for Solar-Rice Husk Hybrid power plant to harness electricity from the hybrid system in context of Nepal and other agricultural based country.

\section{Abbreviations}

$\begin{array}{ll}\text { INPS } & \text { Integrated Nepal Power System } \\ \text { MW } & \text { Megawatt } \\ \text { NEA } & \text { Nepal Electrical Authority } \\ \text { IPP } & \text { Independent Power Producer } \\ \text { GDP } & \text { Gross Domestic Product } \\ \text { kWh } & \text { Kilo Watt Hour } \\ \text { kW } & \text { Kilowatt } \\ \text { kg } & \text { Kilogram } \\ \text { GWh } & \text { Giga Watt Hour }\end{array}$

\section{Research Highlights}

i. Rice husk growth rate of Nepal was found.

ii. Rice husk potential of Nepal was calculated up to the year 2030 . 
iii. Electricity potential through hybrid system was found up to year 2030.

iv. Potential for Jhapa district was found to be highest for the year 2015.

v. Potential for Mahottary district was found to be lowest for the year 2015 .

\section{Acknowledgements}

This study is supported by 2016 Research Grant from University Grants commission, Nepal.

\section{References}

[1] Central Bureau of Statistics. (1987, 1991, 2001, 2003, 2009, 2014, 2015). Statistial Year book. Kathmandu: Government of Nepal National Planning Commission Secretariat Central Bureau of Statistics Ramshahpath, Thapathali Kathmandu, Nepal.

[2] Ministry of Agricultural Development. (2014). Statistical Information of Nepalese Agriculture. Kathmandu:

Government of Nepal, Ministry of Agricultural Development, Agribusiness Promotion and Statistics Division, AgriStatistics section, Singha Durbar, Kathmandu.

[3] Nepal Electrical Authority. (2014, 2015, 2016, 2017, 2018). Annual Report-2014. Kathmandu: Nepal Electrical Authority.

[4] WECS. (2017, January). Electricity Demand Forecast Report ministry of energy. Retrieved from www.moen.gov.np/pdf_files/Electricity-Demand-ForecastReport-2014-2040.pdf.

[5] Smith, J. (2007, November 1). Combined Heat and Power from Rice Husk. Retrieved from www.bioenergyconsult.com/tag/rice-husk/.

[6] Zafar, S. (2015, November 29). Bioenergy Consult accessed on 13th June 2016. Retrieved from www.bioenergyconsult.com/tag/rice-husk/.
[7] Bhattacharayya, S. C. (2014). Viability of off-grid electricity supply using rice husk: A case study from South Asia. Biomass and Bioenergy, 44-54.

[8] Sahoo, U. (2015). Scope and sustainability of hybrid solar. Renewable and Sustainable Energy Reviews, 304-316.

[9] Asian Development Bank. (2013). Solid Waste Management in Nepal Current Status and Policy Recommendations. Retrieved from https://www.adb.org/.../30366/solid-wastemanagement-nepal.pdf.

[10] Hitofumi Abe, A. K. (2007). Potential for rural electrification based on biomass gasification. Biomass and Bioenergy, 656664.

[11] Blezinger, S. B. (2003). some by-product feeds can be used to add extra fiber. Retrieved from www.cattletoday.com/archive/2003/March/CT257.shtml accessed on $7 / 2 / 2016$.

[12] Md. Risat Abedin, H. S. (2014). Electricity from Rice Husk: A Potential Way to Electrify Rural Bangladesh. International Journal of Renewable Energy Research, 604-609.

[13] T.Srinivas. (2014). Hybrid solar-biomass power plant without energy storage. case studies in thermal engineering, 75-81.

[14] World Bank. (n.d.). GDP growth (annual \%) | Data - World Bank Data - World Bank Group. Retrieved from https://data.worldbank.org/indicator/NY.GDP.MKTP.KD.ZG?1 ocations $=\mathrm{EG}$.

[15] World Bank. (n.d.). Agriculture, value added (annual \% growth) - World Bank Data. Retrieved from https://data.worldbank.org/indicator/NV.AGR.TOTL.KD.ZG.

[16] National Statistics office, Central Bureau of Statistics, Nepal. (2017). GDP shared by different sectors. Kathmandu: Unpublished data.

[17] World Bank. (n.d.). Population growth (annual \%) | Data World Bank Open Data. Retrieved from https://data.worldbank.org/indicator/SP.POP.GROW. 